122

Received: October 26, 2016

Accepted: November 11, 2016
Journal of Electrical Engineering and Information Technologies, Vol. 1, No. 1-2, pp. 7-15 (2016)

In print: ISSN $2545-4250$

On line: ISSN 2545-4269

UDC: $551.551 / .552: 621.311 .245(497.7)$

Original scientific paper

\title{
WIND PARAMETERS ANALYSIS ON FIVE LOCATIONS IN MACEDONIA -- THE SECOND MEASUREMENT CAMPAIGN -
}

\author{
Kiril Demerdžiev, Živko Kokolanski, Vladimir Dimčev, \\ Maja Celeska, Krste Najdenkoski, Vlatko Stoilkov \\ Faculty of Electrical Engineering and Information Technologies, \\ "Ss. Cyril and Methodius" University in Skopje, \\ Rugjer Bošković bb, P.O. box 574, 1001 Skopje, Republic of Macedonia \\ kdemerdziev@feit.ukim.edu.mk
}

\begin{abstract}
A b s t r a c t: The world population growth and the technological development have increased the demands for electricity. Because of the limited deposits of fossil fuel and the negative impact its combustion causes to the environment, the electricity production technologies are orienting towards using the renewable energy sources. From all the renewable energy sources, the most studied one over the last decade is the wind. Wind parameters of interest in electrical study are its speed and direction; once they are measured it is easy to determine other characteristic parameters such as wind energy density on the specific location. In the manuscript, monthly and seasonal mean wind speeds are presented, alongside the wind energy density for five locations in the Republic of Macedonia, for almost four years of measurements.
\end{abstract}

Key words: monthly mean wind speeds; seasonal mean wind speed; scale parameter; shape parameter;

wind energy density

\section{АНАЛИЗА НА ПАРАМЕТРИТЕ НА ВЕТРОВИТЕ НА ПЕТ ЛОКАЦИИ ВО МАКЕДОНИЈА - ВТОРА МЕРНА КАМПАЊА -}

А п с т р а к т: Последицата од зголемувањето на популацијата на светско ниво и од големиот технолошки развој е сѐ поголемата побарувачка на електрична енергија. Имајќи ги предвид ограничените наоѓалишта на фосилни горива и негативното влијание на нивното согорување врз животната средина, производствените технологии сѐ повеќе се ориентирааат кон искористување на обновливите извори на енергија. Од сите обновливи извори, најголема енергија е акумулирана во ветерот. Параметрите на ветерот кои се од интерес за негово проучување од електроенергетски аспект се, пред сѐ, неговата брзина и насока, а од нив се изведуваат и други карактеристични параметри како што е, на пример, густината на енергија на конкретна локација. Во овој труд се прикажани средните брзини на ветерот на месечно и сезонско ниво, како и густините на енергија кои ги поседува ветерот во одделни месеци, односно сезони, во текот на една година. Анализата е направена за пет локации на територијата на Република Македонија, за речиси петгодишен период на испитување.

Клучни зборови: средна сезонска брзина; средна месечна брзина; параметар на размер; параметар на форма; густина на ветерна енергија

\section{INTRODUCTION}

The first measurement campaign for establishing a wind database in the Republic of Macedonia was successfully completed with the construction of Wind Park Bogdanci, the second campaign was carried on in the period between July 2012 and
March 2016. In the second wind measurement campaign five locations were chosen according to several relevant factors $[1,2]$, such as:

- Wind atlas of Macedonia;

- Terrain configuration;

- Local infrastructure - proximity of electrical network and roads, etc. 
The sites where the measurement campaign took place are: Staro Nagoričane, Sveti Nikole, Berovo, Mogila and Sopište. The measurement campaign started during the summer of 2012 and covered a continuous process of data acquisition except for some time intervals when certain malfunction in the equipment took place. In Table 1 the geographical coordinates of all five locations are presented, alongside with the altitude and the day when measurements began. Measured data from the measurement stations are sent to data center on a daily or half-day basis in a binary files with extension *rwd (Raw Wind Data) [1]. In order to have this files read and interpret, they have to be converted in text files using the software Symphony Data Retriever, NRG Systems. Once the data is converted in $t \times t$ format, it's easy to use it for wind energy estimation, by inserting it in some advanced software.

Table 1

Measurements sites

\begin{tabular}{|c|c|c|c|}
\hline Site & $\begin{array}{l}\text { Geographical } \\
\text { coordinates }\end{array}$ & $\begin{array}{l}\text { Altitude } \\
\text { (m) }\end{array}$ & $\begin{array}{c}\text { Measurement } \\
\text { start }\end{array}$ \\
\hline Sveti Nikole & $\begin{array}{l}\text { N } 041^{\circ} 55.093^{\prime} \\
\text { E } 021^{\circ} 56.792^{\prime}\end{array}$ & 431 & 1. 7. 2012 \\
\hline Mogila & $\begin{array}{l}\mathrm{N} 041^{\circ} 11.303^{\prime} \\
\text { E } 021^{\circ} 21.546^{\prime}\end{array}$ & 702 & 20.7. 2012 \\
\hline $\begin{array}{l}\text { Staro } \\
\text { Nagoričane }\end{array}$ & $\begin{array}{l}\text { N } 042^{\circ} 18.070^{\prime} \\
\text { E } 021^{\circ} 58.504^{\prime}\end{array}$ & 1179 & 26. 8. 2012 \\
\hline Berovo & $\begin{array}{l}\text { N } 041^{\circ} 44.042^{\prime} \\
\text { E } 022^{\circ} 47.059^{\prime}\end{array}$ & 608 & 21.9. 2012 \\
\hline Sopište & $\begin{array}{l}\mathrm{N} 041^{\circ} 11.299^{\prime} \\
\mathrm{E} 021^{\circ} 21.562^{\prime}\end{array}$ & 730 & 22.9. 2012 \\
\hline
\end{tabular}

\section{WIND ENERGY PARAMETERS}

The term wind energy actually means a kinetic energy which a floating wind mass possess when it moves on some distance above Earth's surface [3]. The power accumulated in the air mass with density $\rho\left(\mathrm{kg} / \mathrm{m}^{3}\right)$, moving at speed $v(\mathrm{~m} / \mathrm{s})$ is given by:

$$
P=\frac{1}{2} \rho A v^{3},
$$

where $A\left(\mathrm{~m}^{2}\right)$ is a blade sweep area.

As can be seen from (1), the power accumulated in wind depends on the air density and the cube of wind velocity. Further on, the air density depends on the air temperature and pressure, while the wind speed depends on the distance between the measuring point and the surface. The wind speed is also affected by roughness on Earth's surface such as: urban areas, rocky terrains, forests, etc.
In order, an initial assessment of the wind profile to be made, the mean wind speed is measured [4]:

$$
v_{m}=\frac{1}{n} \sum_{i=1}^{n} v_{i},
$$

where $n$ is the total number of measurements registered over given time period. It is not enough only the mean wind speed, but also one has to know the wind's distribution. The wind's distribution shows what values the wind speed may have on that particular location and the percentage of time when the wind blows with particular speed. Location with high energy potential is a location where the wind speed is high enough to cause nominal energy production from the turbine and all the wind speed deviate minimally from the mean value. In order to estimate the deviation from the mean value the standard deviation is used:

$$
\sigma=\sqrt{\frac{\sum_{i=1}^{n}\left(v_{i}-v_{m}\right)^{2}}{n-1}} .
$$

Wind speed variations can be calculated using some standard distribution function. Suitable distribution function for such a purpose is the Weibull distribution [5]. Using the Weibull distribution the probability function and cumulative probability functions can be calculated using:

$$
\begin{gathered}
f(v)=\frac{k}{c}\left(\frac{v}{c}\right)^{k-1} e^{-(v / c)^{k}}, \\
F\left(v_{1}\right)=\int_{0}^{\infty} f(v) \partial v=1-e^{(v / c)^{k}} .
\end{gathered}
$$

In both probability functions two parameters can be spotted: scale parameter $c$ (in units of speed) and shape parameter $k$ (dimensionless number). The scale parameter $c$ value is related to the value of mean wind speed and the shape parameter $k$ value is related to the standard deviation and the uniformity of the wind speed in a given site, the greater standard deviation the smaller shape parameter [6]. These two parameters vary on different sites and different observation periods. Their values are given with following equations:

$$
\begin{aligned}
& k=\left(\frac{\sigma}{v_{m}}\right)^{-1.086}, \\
& c=\frac{v_{m}}{\Gamma\left(1+\frac{1}{k}\right)},
\end{aligned}
$$

where $\Gamma$ is the gamma function. In general, these two parameters determine the wind speed range over which the wind turbine is likely to operate. 
By using (1) and (4), the wind energy density can be calculated. Wind energy density is expressed in $\mathrm{W} / \mathrm{m}^{2}$ and is an indicator for the wind energy available on the location which can be further transformed into electricity [6, 7]. Because not only the mean speed, but the distribution as well is taken into account, power density is better indicator for wind energy potential than the mean speed. Wind energy power density can be calculated using:

$$
\frac{P_{W}}{A}=\int_{0}^{\infty} \frac{1}{2} \rho v^{3} f(v) \partial v=\frac{1}{2} \rho c^{3} \Gamma\left(1+\frac{3}{k}\right)
$$

\section{WIND SPEED DATA ANALYSIS}

In this study, mean wind speed on monthly and seasonal basis is calculated for all five measurement sites, during the duration of measurement campaign. Scale and shape parameters alongside the wind energy density for every month/season are calculated as well. All the values are presented in separate tables. The monthly mean speed is calculated as average value per month from all daily mean speed values. The seasonal mean speed is calculated the same way, only the daily averages are regrouped in four year seasons as follows: spring March 21 to June 20, summer June 21 to September 22, autumn September 2 to December 20 and winter December 21 to March 20.

The calculation of monthly and seasonal wind mean speed is done using MS Excel software tool. The first step is to generate monthly reports for each measurement site using Symphony Data Retriever and save them to *.pdf format. The monthly PDFs are then converted to Excel files. When all the Excel files for one location are merged to one the calculation can be made. By using daily speed averages for every day in the year, standard deviation is calculated on monthly and seasonal basis. Shape parameter, scale parameter as well as wind energy densities are calculated from mean wind speed and standard deviation using equations (6), (7) and (8).

\section{Sveti Nikole}

In Table 2, the monthly mean wind speed is presented, alongside the values for shape and scale parameter and wind energy density for each month in the year, at Sveti Nikole measurement site.

The highest mean wind speed is $5.16 \mathrm{~m} / \mathrm{s}$ and is calculated for June and July, while the lowest value is calculated for November and it is 3.75 $\mathrm{m} / \mathrm{s}$. The standard deviation calculated for all months except for August is higher than $1 \mathrm{~m} / \mathrm{s}$ which means that daily mean speeds differ significantly of the monthly mean value. This fact is verified with values in the fourth column of the table, where the shape parameter is presented. The shape parameter varies between 2.55 in December and 5.48 in August. Even though mean wind speed is equal for June and July, the wind energy density slightly differs in this two months, $100.35 \mathrm{~W} / \mathrm{m}^{2}$ in June and $96,8 \mathrm{~W} / \mathrm{m}^{2}$ in July.

Table 2

Calculated data on monthly basis at Sveti Nikole

\begin{tabular}{cccccc}
\hline \hline Month & $\begin{array}{c}\text { Mean wind } \\
\text { speed } \\
(\mathrm{m} / \mathrm{s})\end{array}$ & $\begin{array}{c}\text { Standard } \\
\text { deviation } \\
(\mathrm{m} / \mathrm{s})\end{array}$ & $\begin{array}{c}\text { Parameter } \\
\text { Shape }\end{array}$ & $\begin{array}{c}\text { Scale } \\
c(\mathrm{~m} / \mathrm{s})\end{array}$ & $\begin{array}{c}\text { Wind energy } \\
\text { density } \\
\left(\mathrm{W} / \mathrm{m}^{2}\right)\end{array}$ \\
\hline 1 & 4.28 & 1.63 & 2.85 & 4.81 & 69.61 \\
2 & 4.93 & 1.91 & 2.79 & 5.53 & 107.23 \\
3 & 4.82 & 1.73 & 3.04 & 5.40 & 95.72 \\
4 & 5.09 & 1.67 & 3.35 & 5.67 & 107.35 \\
5 & 4.06 & 1.59 & 2.76 & 4.57 & 60.63 \\
6 & 5.16 & 1.31 & 4.41 & 5.66 & 100.35 \\
7 & 5.16 & 1.17 & 5.02 & 5.61 & 96.80 \\
8 & 4.08 & 0.85 & 5.48 & 4.42 & 47.16 \\
9 & 4.17 & 1.13 & 4.14 & 4.59 & 54.09 \\
10 & 4.04 & 1.13 & 3.99 & 4.46 & 50.05 \\
11 & 3.75 & 1.16 & 3.57 & 4.16 & 41.67 \\
12 & 4.02 & 1.70 & 2.55 & 4.53 & 61.91 \\
\hline \hline
\end{tabular}

For this measurement location it can be concluded that the wind energy density does not follow the value of mean wind speed, and so the highest wind energy density is calculated for February and April. The change in mean wind speed by month is presented on Figure 1.

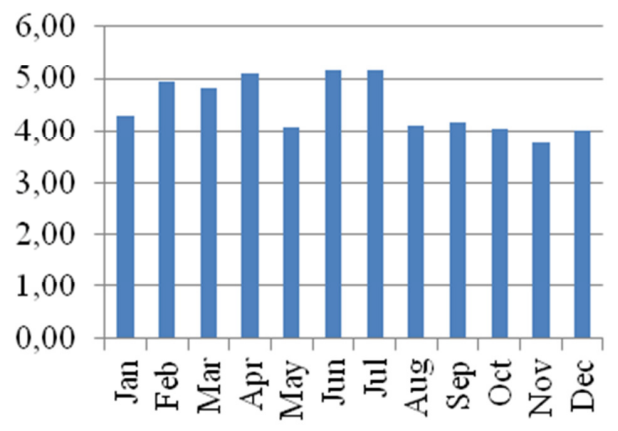

Fig. 1. Monthly mean wind speed at Sveti Nikole $(\mathrm{m} / \mathrm{s})$ 
The same data, but averaged over time period of one season is presented in Table 3. The seasonal mean wind speed is the highest in summer and the lowest in winter, values are $4.64 \mathrm{~m} / \mathrm{s}$ and $3.99 \mathrm{~m} / \mathrm{s}$ respectively. High value for the mean speed is also calculated for spring period, $4.62 \mathrm{~m} / \mathrm{s}$. The change in mean wind speed on season basis is illustrated on Figure 2. The greatest variations around the mean value are noticed in winter period, which can be seed by standard deviation and shape parameter values $1.75 \mathrm{~m} / \mathrm{s}$ and 2.84 respectively. The scale parameter value varies between $4.44 \mathrm{~m} / \mathrm{s}$ in autumn and 5.14 in spring. Wind energy density is the highest in winter, $84.8 \mathrm{~W} / \mathrm{m}^{2}$, and the lowest in autumn, $50.74 \mathrm{~W} / \mathrm{m}^{2}$.

Table 3

\section{Calculated data on seasonal basis at Sveti Nikole}

\begin{tabular}{|c|c|c|c|c|c|}
\hline \multirow[b]{2}{*}{ Season } & \multirow{2}{*}{$\begin{array}{c}\text { Mean wind } \\
\text { speed } \\
(\mathrm{m} / \mathrm{s})\end{array}$} & \multirow{2}{*}{$\begin{array}{c}\text { Standard } \\
\text { deviation } \\
(\mathrm{m} / \mathrm{s})\end{array}$} & \multicolumn{2}{|c|}{ Parameter } & \multirow{2}{*}{$\begin{array}{c}\text { Wind energy } \\
\text { density } \\
\left(\mathrm{W} / \mathrm{m}^{2}\right)\end{array}$} \\
\hline & & & $\begin{array}{c}\text { Shape } \\
k\end{array}$ & $\begin{array}{l}\text { Scale } \\
c(\mathrm{~m} / \mathrm{s})\end{array}$ & \\
\hline Spring & 4.62 & 1.48 & 3.43 & 5.14 & 79.28 \\
\hline Summer & 4.64 & 1.17 & 4.45 & 5.09 & 72.95 \\
\hline Autumn & 3.99 & 1.26 & 3.50 & 4.44 & 50.74 \\
\hline Winter & 4.57 & 1.75 & 2.84 & 5.13 & 84.80 \\
\hline
\end{tabular}

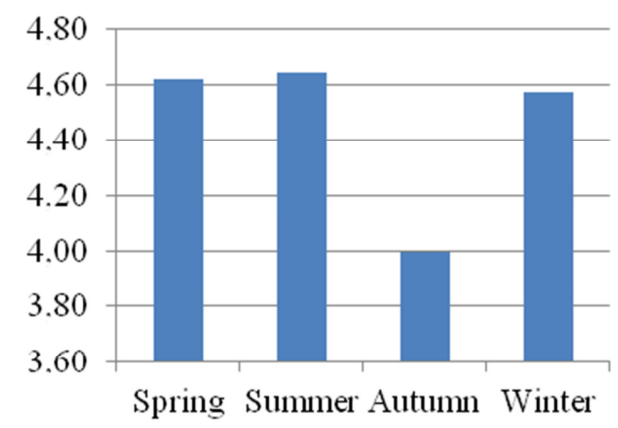

Fig. 2. Seasonal mean wind speed at Sveti Nikole $(\mathrm{m} / \mathrm{s})$

\section{Mogila}

The mean wind speed, standard deviation, shape parameter, scale parameter and wind energy density calculated on monthly basis at this site are presented in Table 4. The two months where the highest mean speed is found are February and April, $4.51 \mathrm{~m} / \mathrm{s}$ and $4.41 \mathrm{~m} / \mathrm{s}$ respectively. The lowest monthly mean wind speed is $2.32 \mathrm{~m} / \mathrm{s}$ and is calculated for December. Visually monthly mean wind speed change from month to month is illustrated on Figure 3.
Table 4

Calculated data on monthly basis at Mogila

\begin{tabular}{cccccc}
\hline \hline Month & $\begin{array}{c}\text { Mean wind Standard } \\
\text { speed } \\
(\mathrm{m} / \mathrm{s})\end{array}$ & $\begin{array}{c}\text { Parameter } \\
\text { deviation } \\
(\mathrm{m} / \mathrm{s})\end{array}$ & $\begin{array}{c}\text { Shape } \\
k\end{array}$ & $\begin{array}{c}\text { Scale } \\
c(\mathrm{~m} / \mathrm{s})\end{array}$ & $\begin{array}{c}\text { Wind energy } \\
\text { density } \\
\left(\mathrm{W} / \mathrm{m}^{2}\right)\end{array}$ \\
\hline 1 & 3.66 & 1.37 & 2.90 & 4.11 & 43.05 \\
2 & 4.51 & 1.75 & 2.80 & 5.07 & 82.18 \\
3 & 4.17 & 1.51 & 3.02 & 4.67 & 62.32 \\
4 & 4.41 & 1.56 & 3.09 & 4.94 & 72.84 \\
5 & 3.55 & 1.41 & 2.73 & 3.99 & 40.61 \\
6 & 3.59 & 0.94 & 4.27 & 3.94 & 34.14 \\
7 & 3.72 & 0.83 & 5.09 & 4.05 & 36.19 \\
8 & 3.30 & 0.42 & 9.41 & 3.47 & 22.99 \\
9 & 3.47 & 0.56 & 7.25 & 3.70 & 27.54 \\
10 & 3.28 & 0.79 & 4.68 & 3.59 & 25.40 \\
11 & 3.07 & 0.89 & 3.82 & 3.40 & 22.31 \\
12 & 2.32 & 0.95 & 2.65 & 2.61 & 11.59 \\
\hline \hline
\end{tabular}

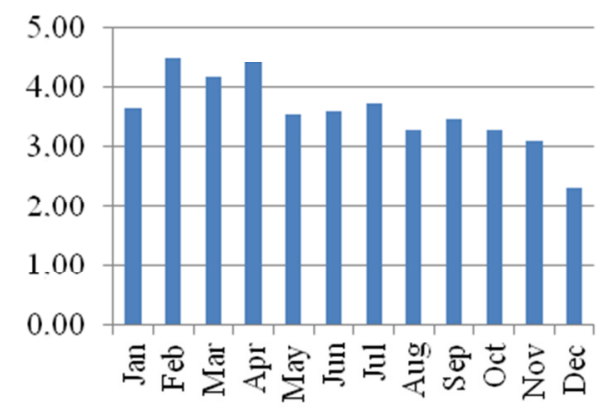

Fig. 3. Monthly mean wind speed at Mogila (m/s)

In the first five months standard deviation possess high values (higher than $1 \mathrm{~m} / \mathrm{s}$ ) which can also be noticed by observing the shape parameter, which varies from 2.80 to 3.10 , for the period from January to May.

The deviation between the monthly mean speed and daily average speeds is the lowest in August, when the standard deviation is $0.42 \mathrm{~m} / \mathrm{s}$ and the shape parameter is 9.41 . Scale parameter follows the variation of mean wind speed from month to month and its value changes between $2.61 \mathrm{~m} / \mathrm{s}$ in December and $5.07 \mathrm{~m} / \mathrm{s}$ in February. Wind energy density also follows changes in mean speed and scale parameter, the lowest value is noticed in December, only $11.59 \mathrm{~W} / \mathrm{m}^{2}$, while the highest are found in February and April, 82.18 $\mathrm{W} / \mathrm{m}^{2}$ and $72.84 \mathrm{~W} / \mathrm{m}^{2}$ respectively.

In Table 5 the same data averaged over one year, with averaging time of one season is presented. The mean wind speed in all seasons varies be- 
tween $3 \mathrm{~m} / \mathrm{s}$ and $4 \mathrm{~m} / \mathrm{s}$, the highest spotted at winter, equals $3.92 \mathrm{~m} / \mathrm{s}$, the lowest spotted at autumn, its value is $3.01 \mathrm{~m} / \mathrm{s}$. The mean speed histogram is presented on Figure 4.

Table 5

\section{Calculated data on seasonal basis at Mogila}

\begin{tabular}{lccccc}
\hline \hline Season & $\begin{array}{c}\text { Mean wind } \\
\text { speed } \\
(\mathrm{m} / \mathrm{s})\end{array}$ & $\begin{array}{c}\text { Standard } \\
\text { deviation } \\
(\mathrm{m} / \mathrm{s})\end{array}$ & $\begin{array}{c}\text { Parameter } \\
k\end{array}$ & $\begin{array}{c}\text { Shape } \\
c(\mathrm{~m} / \mathrm{s})\end{array}$ & $\begin{array}{c}\text { Wind energy } \\
\text { density } \\
\left(\mathrm{W} / \mathrm{m}^{2}\right)\end{array}$ \\
\hline Spring & 3.87 & 1.34 & 3.16 & 4.32 & 48.45 \\
Summer & 3.52 & 0.67 & 6.10 & 3.79 & 29.50 \\
Autumn & 3.01 & 0.84 & 4.02 & 3.32 & 20.61 \\
Winter & 3.92 & 1.51 & 2.83 & 4.40 & 53.55 \\
\hline \hline
\end{tabular}

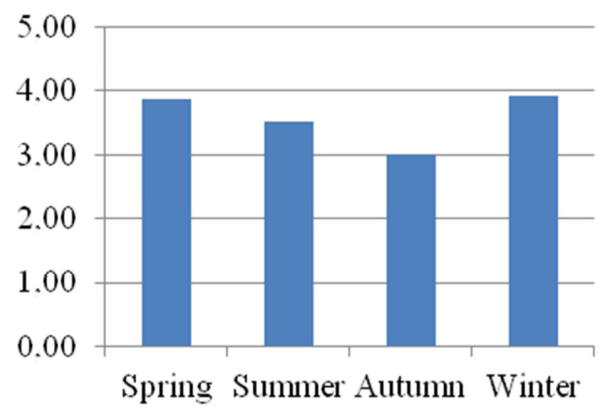

Fig. 4. Seasonal mean wind speed at Mogila (m/s)

During the summer and winter daily mean wind speed differs less from the average seasonal value. This conclusion is affirmed by the values of standard deviation and shape parameter during summer period. The variations round the mean value are the lowest in the winter. The shape parameter values for summer and winter are 6.10 and 2.83 respectively. Because of the small mean wind speed variation from season to season, the scale parameter changes between the values of $3.32 \mathrm{~m} / \mathrm{s}$ at autumn and $4.40 \mathrm{~m} / \mathrm{s}$ at winter. The wind energy density is the highest at winter, while the lowest at autumn.

\section{Staro Nagoričane}

In Table 6, mean wind speed is presented, as well as Weibull parameters of scale and shape, and wind energy density all averaged over one year time, with a period of averaging of one month. From the table it can be noticed that the highest monthly mean speeds are present in February, June and November, while the lowest value is found in August. The magnitudes of the mean wind speed in top three months are $7.22 \mathrm{~m} / \mathrm{s}, 6.57 \mathrm{~m} / \mathrm{s}$ and 6.70 $\mathrm{m} / \mathrm{s}$, respectively, while in August it is $5.29 \mathrm{~m} / \mathrm{s}$. The monthly mean speeds are presented on Figure 5. On this location, in January, huge variations between the mean speed and daily averages are presented.

Table 6

Calculated data on monthly basis at Staro Nagoričane

\begin{tabular}{cccccc}
\hline \hline \multicolumn{5}{c}{ Mean wind Standard } \\
Month & $\begin{array}{c}\text { Parameter } \\
\text { speed } \\
(\mathrm{m} / \mathrm{s})\end{array}$ & $\begin{array}{c}\text { deviation } \\
(\mathrm{m} / \mathrm{s})\end{array}$ & $\begin{array}{c}\text { Shape } \\
\mathrm{k}\end{array}$ & $\begin{array}{c}\text { Scale } \\
\mathrm{c}(\mathrm{m} / \mathrm{s})\end{array}$ & $\begin{array}{c}\text { Wind energy } \\
\text { density }\end{array}$ \\
\hline 1 & 6.66 & 2.28 & 3.20 & 7.43 & 245.08 \\
2 & 7.22 & 1.97 & 4.11 & 7.95 & 281.45 \\
3 & 6.55 & 1.10 & 6.95 & 7.01 & 186.69 \\
4 & 5.89 & 1.72 & 3.81 & 6.52 & 157.37 \\
5 & 5.75 & 1.69 & 3.78 & 6.36 & 146.70 \\
6 & 6.57 & 1.65 & 4.49 & 7.20 & 206.30 \\
7 & 6.31 & 1.37 & 5.27 & 6.86 & 175.76 \\
8 & 5.29 & 0.89 & 6.96 & 5.65 & 97.96 \\
9 & 5.65 & 1.28 & 5.01 & 6.15 & 127.59 \\
10 & 5.96 & 1.26 & 5.40 & 6.47 & 147.36 \\
11 & 6.70 & 1.66 & 4.54 & 7.34 & 218.08 \\
12 & 5.77 & 1.51 & 4.30 & 6.34 & 141.80 \\
\hline \hline
\end{tabular}

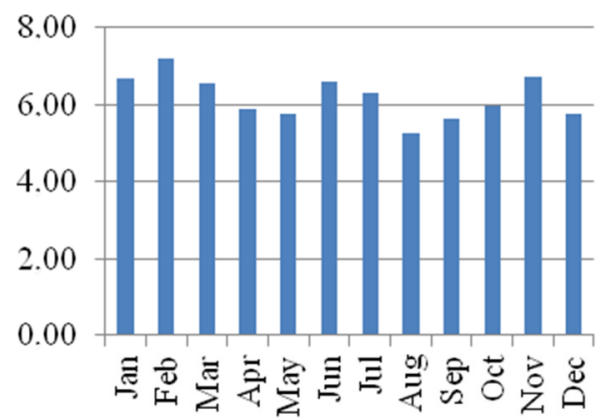

Fig. 5. Monthly mean wind speed at Staro Nagoričane $(\mathrm{m} / \mathrm{s})$

The value of standard deviation is $2.28 \mathrm{~m} / \mathrm{s}$, while the shape parameter is 3.20 . It is all the opposite in August, in this month the lowest from day to day variations are spotted, therefore the standard deviation is only $0.89 \mathrm{~m} / \mathrm{s}$ and the $k$ parameter is almost 7. Shape parameter in each month is approximately for $1 \mathrm{~m} / \mathrm{s}$ higher than the mean wind speed in that particular month. From the changes in shape parameter the change in the wind energy density is calculated. The wind potential is the highest in February, while the lowest in August. The wind energy density changes from 97.96 $\mathrm{W} / \mathrm{m}^{2}$ to $281.45 \mathrm{~W} / \mathrm{m}^{2}$. 
The seasonal mean wind speed, alongside other Weibull parameters is presented in Table 7. As can be seen from Table 7, the wind blows at the highest speed during the winter, the mean value to be $6.68 \mathrm{~m} / \mathrm{s}$. During the summer period the lowest wind speed is present, together with the lowest variations between the seasonal and daily mean wind speeds. This fact can be noticed by observing the third and fourth column in Table 7. For the summer period the standard deviation is $1.27 \mathrm{~m} / \mathrm{s}$ and the shape parameter is 5.29. The value of $c$ parameter is higher than the mean speed and it varies from $6.38 \mathrm{~m} / \mathrm{s}$ in summer to $7.38 \mathrm{~m} / \mathrm{s}$ in winter. The wind energy density varies between 141.68 $\mathrm{W} / \mathrm{m}^{2}$ and $166.38 \mathrm{~W} / \mathrm{m}^{2}$ for the spring-autumn period, while at winter its value is much higher, $227.07 \mathrm{~W} / \mathrm{m}^{2}$. The change in mean wind speed on season basis is illustrated on Figure 6.

Table 7

\section{Calculated data on seasonal basis at Staro Nagoričane}

\begin{tabular}{lccccc}
\hline \hline Season & $\begin{array}{c}\text { Mean wind } \\
\text { speed } \\
(\mathrm{m} / \mathrm{s})\end{array}$ & $\begin{array}{c}\text { Standard } \\
\text { deviation } \\
(\mathrm{m} / \mathrm{s})\end{array}$ & $\begin{array}{c}\text { Parameter } \\
\text { Shape }\end{array}$ & $\begin{array}{c}\text { Scale } \\
c(\mathrm{~m} / \mathrm{s})\end{array}$ & $\begin{array}{c}\text { Wind energy } \\
\text { density } \\
\left(\mathrm{W} / \mathrm{m}^{2}\right)\end{array}$ \\
\hline Spring & 6.04 & 1.56 & 4.33 & 6.63 & 161.81 \\
Summer & 5.88 & 1.27 & 5.29 & 6.38 & 141.68 \\
Autumn & 6.16 & 1.43 & 4.90 & 6.72 & 166.38 \\
Winter & 6.68 & 1.89 & 3.93 & 7.38 & 227.07 \\
\hline \hline
\end{tabular}

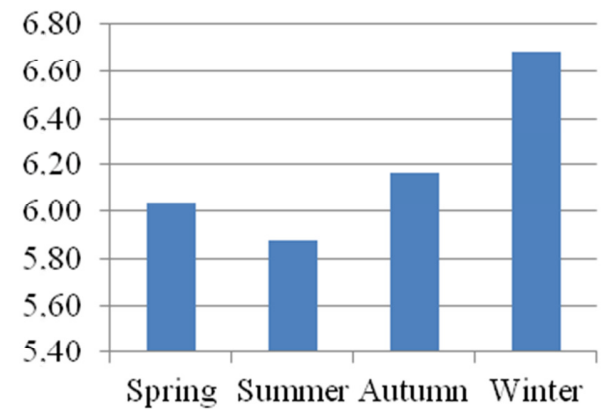

Fig. 6. Seasonal mean wind speed at Staro Nagoričane $(\mathrm{m} / \mathrm{s})$

\section{Berovo}

The measured data, averaged on monthly basis, at Berovo site, is presented on Table 8 and Figure 7. From the table it can be noticed that the highest monthly mean wind speeds are present in February, March and April: $4.21 \mathrm{~m} / \mathrm{s}, 4.18 \mathrm{~m} / \mathrm{s}$ and $4.08 \mathrm{~m} / \mathrm{s}$ respectively while the lowest amounts $3.03 \mathrm{~m} / \mathrm{s}$ is present in August. At this site, it can be noticed that the monthly mean speed in each month is lower than the mean speed at other sites and that there is also a lower variation between the daily averaged wind speed values and the monthly mean value. Except for January and February, the standard deviation is lower than $1 \mathrm{~m} / \mathrm{s}$ and the shape parameter is higher than 5. In August the standard deviation is the lowest and its value is only 0.35 $\mathrm{m} / \mathrm{s}$.

Table 8

Calculated data on monthly basis at Berovo

\begin{tabular}{|c|c|c|c|c|c|}
\hline \multirow[b]{2}{*}{ Month } & \multirow{2}{*}{$\begin{array}{c}\text { Mean wind } \\
\text { speed } \\
(\mathrm{m} / \mathrm{s})\end{array}$} & \multirow{2}{*}{$\begin{array}{c}\text { Standard } \\
\text { deviation } \\
(\mathrm{m} / \mathrm{s})\end{array}$} & \multicolumn{2}{|c|}{ Parameter } & \multirow{2}{*}{$\begin{array}{c}\text { Wind energy } \\
\text { density } \\
\left(\mathrm{W} / \mathrm{m}^{2}\right)\end{array}$} \\
\hline & & & $\begin{array}{c}\text { Shape } \\
k\end{array}$ & $\begin{array}{l}\text { Scale } \\
c(\mathrm{~m} / \mathrm{s})\end{array}$ & \\
\hline 1 & 3.88 & 1.25 & 3.42 & 4.32 & 47.04 \\
\hline 2 & 4.21 & 1.21 & 3.88 & 4.66 & 57.25 \\
\hline 3 & 4.18 & 0.94 & 5.07 & 4.55 & 51.48 \\
\hline 4 & 4.08 & 0.86 & 5.42 & 4.42 & 46.96 \\
\hline 5 & 3.54 & 0.65 & 6.35 & 3.81 & 29.96 \\
\hline 6 & 3.83 & 0.80 & 5.47 & 4.15 & 39.00 \\
\hline 7 & 3.68 & 0.79 & 5.30 & 3.99 & 34.62 \\
\hline 8 & 3.03 & 0.35 & 10.45 & 3.18 & 17.73 \\
\hline 9 & 3.27 & 0.49 & 7.83 & 3.48 & 22.94 \\
\hline 10 & 3.27 & 0.58 & 6.54 & 3.51 & 23.46 \\
\hline 11 & 3.33 & 0.85 & 4.42 & 3.65 & 26.96 \\
\hline 12 & 3.24 & 0.83 & 4.38 & 3.55 & 24.89 \\
\hline
\end{tabular}

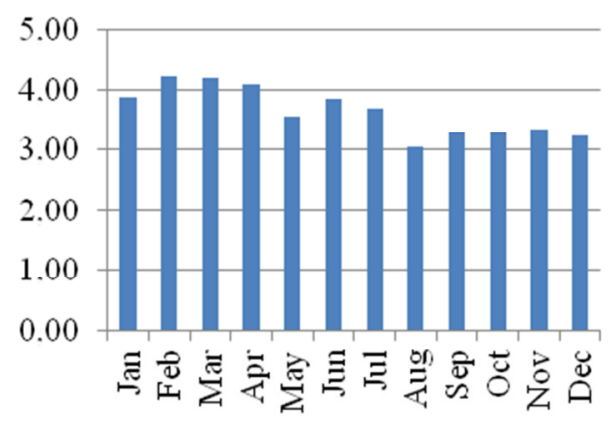

Fig. 7. Monthly mean wind speed at Berovo $(\mathrm{m} / \mathrm{s})$

The scale parameter for every month is approximately $0.4 \mathrm{~m} / \mathrm{s}$ higher than the mean wind speed. Because of the low mean wind speed and with low scale parameter, the wind energy potential is the lowest from all measurement sites. The wind energy density is the highest in February, 57.25 $\mathrm{W} / \mathrm{m}^{2}$, while the lowest in August, $17.73 \mathrm{~W} / \mathrm{m}^{2}$. 
The seasonally averaged data are presented in Table 9. During the winter days the highest mean wind speed is $3.97 \mathrm{~m} / \mathrm{s}$, while the lowest $3.29 \mathrm{~m} / \mathrm{s}$ are calculated for autumn. In the winter period the standard deviation is the highest, $1.12 \mathrm{~m} / \mathrm{s}$, which means the $k$ parameter would be the lowest, 3.98. The scale parameter is higher than $4.2 \mathrm{~m} / \mathrm{s}$ in spring and winter, while in summer and autumn it amounts $3.58 \mathrm{~m} / \mathrm{s}$ and $3.57 \mathrm{~m} / \mathrm{s}$. The wind energy density is relatively low, it changes from value of $24.83 \mathrm{~W} / \mathrm{m}^{2}$ in autumn to $47.57 \mathrm{~W} / \mathrm{m}^{2}$ in winter. The mean speed histogram is presented on Figure 8.

Table 9

\section{Calculated data on seasonal basis at Berovo}

\begin{tabular}{lccccc}
\hline \hline Season & $\begin{array}{c}\text { Mean wind } \\
\text { speed } \\
(\mathrm{m} / \mathrm{s})\end{array}$ & $\begin{array}{c}\text { Standard } \\
\text { deviation } \\
(\mathrm{m} / \mathrm{s})\end{array}$ & $\begin{array}{c}\text { Shape } \\
k\end{array}$ & $\begin{array}{c}\text { Parameter } \\
c(\mathrm{~m} / \mathrm{s})\end{array}$ & $\begin{array}{c}\text { Scale } \\
\text { Wind energy } \\
\text { density } \\
\left(\mathrm{W} / \mathrm{m}^{2}\right)\end{array}$ \\
\hline Spring & 3.89 & 0.81 & 5.47 & 4.22 & 40.88 \\
Summer & 3.35 & 0.57 & 6.82 & 3.58 & 24.95 \\
Autumn & 3.29 & 0.72 & 5.22 & 3.57 & 24.83 \\
Winter & 3.97 & 1.12 & 3.98 & 4.39 & 47.57 \\
\hline \hline
\end{tabular}

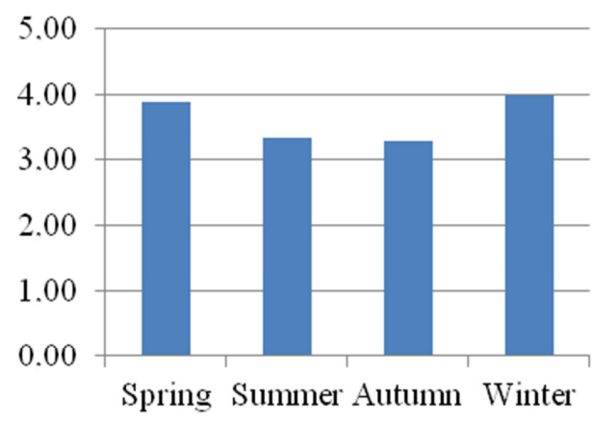

Fig. 8. Seasonal mean wind speed at Berovo $(\mathrm{m} / \mathrm{s})$

\section{Sopište}

In Table 10 and Figure 9, the monthly averaged data for Sopište site are presented. At this site higher mean wind speed is present during the first half of the year. The highest value of $4,51 \mathrm{~m} / \mathrm{s}$ is found in January, while the lowest are calculated in the last three months of the year, their values are $3.29 \mathrm{~m} / \mathrm{s}, 3.24 \mathrm{~m} / \mathrm{s}$ and $3.29 \mathrm{~m} / \mathrm{s}$ respectively. As can be seen from the previous four sites, the highest standard deviation is usually present in the month when the highest wind speed is calculated. So the highest standard deviation is present in January, it amounts $1.86 \mathrm{~m} / \mathrm{s}$. The standard devia- tion is high in February as well, while in other ten months it varies between $0.82 \mathrm{~m} / \mathrm{s}$ in September and $1.15 \mathrm{~m} / \mathrm{s}$ in April. August is the exception with less deviation around the mean value, standard deviation is only $0.63 \mathrm{~m} / \mathrm{s}$. Scale parameter follows the monthly mean wind speed, the parameter has the highest value in January, while the lowest in November. Because of, according to (8), cubic relation between the wind energy density and scale parameter, in January the value amounts 86.02 $\mathrm{W} / \mathrm{m}^{2}$, while in November it is only $25.58 \mathrm{~W} / \mathrm{m}^{2}$.

Table 10

Calculated data on monthly basis at Sopište

\begin{tabular}{cccccc}
\hline \hline Month & $\begin{array}{c}\text { Mean wind Standard } \\
\text { speed } \\
(\mathrm{m} / \mathrm{s})\end{array}$ & $\begin{array}{c}\text { Parameter } \\
(\mathrm{m} / \mathrm{s})\end{array}$ & $\begin{array}{c}\text { Shape } \\
k\end{array}$ & $\begin{array}{c}\text { Scale } \\
c(\mathrm{~m} / \mathrm{s})\end{array}$ & $\begin{array}{c}\text { Wind energy } \\
\text { density } \\
\left(\mathrm{W} / \mathrm{m}^{2}\right)\end{array}$ \\
\hline 1 & 4.51 & 1.86 & 2.62 & 5.08 & 86.02 \\
2 & 3.96 & 1.56 & 2.75 & 4.45 & 56.25 \\
3 & 4.18 & 1.11 & 4.22 & 4.60 & 54.16 \\
4 & 4.15 & 1.15 & 4.04 & 4.57 & 53.75 \\
5 & 4.16 & 1.19 & 3.90 & 4.60 & 54.89 \\
6 & 4.23 & 1.09 & 4.35 & 4.64 & 55.50 \\
7 & 3.92 & 1.05 & 4.19 & 4.31 & 44.85 \\
8 & 3.81 & 0.63 & 7.05 & 4.07 & 36.49 \\
9 & 3.65 & 0.82 & 5.04 & 3.98 & 34.39 \\
10 & 3.29 & 0.98 & 3.72 & 3.65 & 27.76 \\
11 & 3.24 & 0.89 & 4.07 & 3.57 & 25.58 \\
12 & 3.29 & 1.15 & 3.12 & 3.68 & 29.93 \\
\hline \hline
\end{tabular}

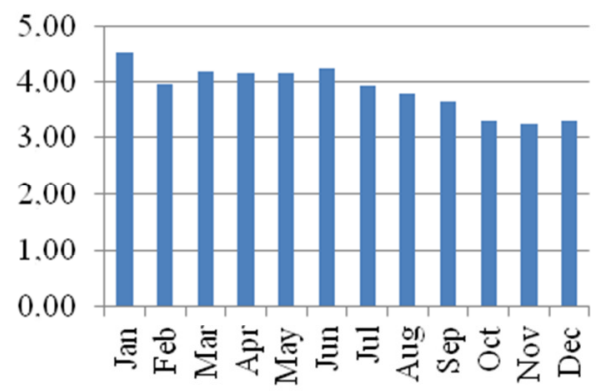

Fig. 9. Monthly mean wind speed at Sopište $(\mathrm{m} / \mathrm{s})$

Seasonal average data is displayed in Table 11. The seasonal mean wind speed is the lowest during the autumn and it amounts $3.31 \mathrm{~m} / \mathrm{s}$, the highest being spotted in the winter months, 4.18 $\mathrm{m} / \mathrm{s}$. During the spring the mean speed value is a bit lower than the winter one. Standard deviation is 
the lowest during the summer period, it amounts only $0.90 \mathrm{~m} / \mathrm{s}$, while in the winter it is $1.52 \mathrm{~m} / \mathrm{s}$. Shape parameter is related to the standard deviation, so it has the highest value in the summer, 4.85 , and the lowest in the winter, 3.00. In all four seasons the scale parameter is approximately 0.4 $\mathrm{m} / \mathrm{s}$ higher than the seasonal mean speed. Wind energy density is the lowest in autumn, it amounts $28.57 \mathrm{~W} / \mathrm{m}^{2}$, while in winter this value is approximately 2.5 times greater. The mean speed histogram is presented on Figure 10.

Table 11

\section{Calculated data on sesonal basis at Sopište}

\begin{tabular}{lccccc}
\hline \hline Season & $\begin{array}{c}\text { Mean wind } \\
\text { speed } \\
(\mathrm{m} / \mathrm{s})\end{array}$ & $\begin{array}{c}\text { Standard } \\
\text { deviation } \\
(\mathrm{m} / \mathrm{s})\end{array}$ & $\begin{array}{c}\text { Parameter } \\
k\end{array}$ & $\begin{array}{c}\text { Shape } \\
c(\mathrm{~m} / \mathrm{s})\end{array}$ & $\begin{array}{c}\text { Wind energy } \\
\text { density } \\
\left(\mathrm{W} / \mathrm{m}^{2}\right)\end{array}$ \\
\hline Spring & 4.10 & 1.08 & 4.28 & 4.51 & 51.07 \\
Summer & 3.86 & 0.90 & 4.85 & 4.21 & 40.87 \\
Autumn & 3.31 & 1.02 & 3.60 & 3.67 & 28.57 \\
Winter & 4.18 & 1.52 & 3.00 & 4.68 & 62.75 \\
\hline \hline
\end{tabular}

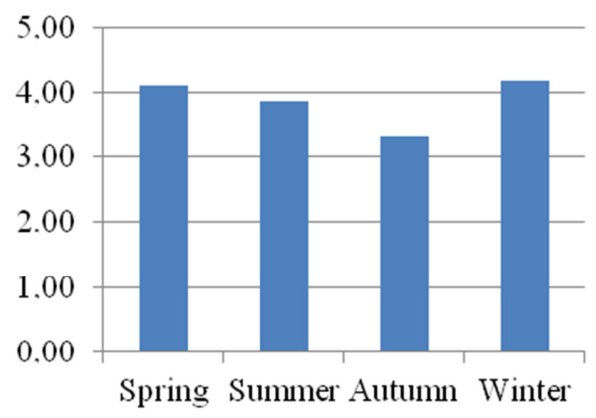

Fig. 10. Seasonal mean wind speed at Sopište $(\mathrm{m} / \mathrm{s})$

\section{SUMMARY AND CONCLUSION}

In the manuscript, the overview of mean wind speed, Weibull parameters and wind energy density has been made, all of them averaged on one month or one year season basis. The analyses are made for five sites on the territory of the Republic of Macedonia, for almost four years of measurement data. For all five measurement sites, all data are presented in separate tables, the mean speed changes during a year time, on monthly or seasonal basis, are also illustrated in form of histograms.

From the tabular data, the similarities and differences at all five sites can be spotted. If one compares wind parameters at Staro Nagoričane with wind parameters at all other sites, the differ- ence is evident in terms of higher mean wind speed and higher wind energy density. At this site the mean wind speed in almost every month/season is higher than $6 \mathrm{~m} / \mathrm{s}$, which is not the case with other sites, where the mean speed barely exceeds $4 \mathrm{~m} / \mathrm{s}$. In both the monthly and seasonal analyses, the wind energy density for each month/season is higher than $100 \mathrm{~W} / \mathrm{m}^{2}$ for Staro Nagoričane, while at other sites this parameter rarely exceeds 60 $\mathrm{W} / \mathrm{m}^{2}$. However, the higher wind speed generally gives the higher variation between the daily averages and the monthly or seasonal mean value. The standard deviation at Staro Nagoričane exceeds 1.5 $\mathrm{m} / \mathrm{s}$ for most of the months/seasons, which is not case for other measurement sites. The measured data, as well as the area of the mountain terrain on this site, qualified Staro Nagoričane as possible location for construction of future wind park. The shortcomings of this location are bad roads and distance to the nearest transmission line.

From other four sites only Sveti Nikole site can be interesting regarding wind energy potential. At Sveti Nikole the mean wind speed reaches 5 $\mathrm{m} / \mathrm{s}$ in certain months/seasons, and energy on surface unit reaches $100 \mathrm{~W} / \mathrm{m}^{2}$.

The one thing that is common for all five sites is the monthly and seasonal wind distribution. At all five sites the highest wind speed is present in winter and the lowest during the autumn. The exception is located only at Staro Nagoričane where the lowest energy potential can be spotted in the summer. On monthly basis, the strongest wind is found in February, while the poorest can be noticed in August.

This measurement campaign together with the first one show that the windiest regions in Macedonia are Ovče Pole and sites in proximity of Vardar valley, like Bogdanci and Gevgelija. Furthermore, in the near future more detailed analyses will be made for Staro Nagoričane location and possibility for building wind park.

Acknowledgements: The project presented herein has been supported by World Bank and Energy Agency of the Republic of Macedonia. The authors would like to express their appreciation for the opportunity to realize this complex project.

\section{REFERENCES}

[1] Vladimir Dimčev, Vlatko Stoilkov, Krste Najdenkovski, Živko Kokolanski, Maja Celeska: Establishing wind energy data base in the Republic of Macedonia, Faculty of Electrical Engineering and IT, Skopje, September 2015.

[2] Vladimir Dimčev, Vlatko Stoilkov, Krste Najdenkovski, Živko Kokolanski, Maja Celeska: Summary report for 
the second wind measurement campaign in the Republic of Macedonia, Faculty of Electrical Engineering and IT, Skopje, April 2016.

[3] Kiril Demerdžiev: Wind energy potential measurement and data analysis, bachelor thesis, Faculty of Electrical Engineering and IT, Skopje, October 2015.

[4] I. Munteanu, A. I. Bratcu, N. A. Cutululis, E. Ceanga: Optimal Control of Wind Energy Systems - Towards a Global Approach, Springer-Verlag, London, 2008.

[5] A. N. Celik: A statistical Analysis of Wind Power Density Based on the Weibull and Rayleigh Models at the Southern Region of Turkey, Renewable Energy, 29, (2), 21-33 (2006).

[6] Mahyoub H. Al-Buhairi, Ahmed Al-Haydari: Monthly and Seasonal Investigation of Wind Characteristics and Assessment of Wind Energy Potential in Al-Mokha, Yemen, Energy and Power Engineering, 4 (3), 125-131 (2012), doi: 10.4236/epe.2012.43017.

[7] Sunday O. Oyedepo, Muyiwa S. Adaramola, Samuel S. Paul: Analysis of wind speed data and wind energy potential in three selected locations in south-east Nigeria, International Journal of Energy and Environmental Engineering, 3 (7), 1-11 (2012) (http://www. journal-ijeee. com/content/3/1/7). 
